\title{
Nicolas-François-Antoine de Chastillon: The Défilement of Fortifications at the Roots of Descriptive Geometry
}

\author{
Laura Carlevaris
}

Published online: 12 November 2014

(C) Kim Williams Books, Turin 2014

\begin{abstract}
This contribution focuses on studies concerning the art of défilement (defilade) of fortifications, that is, the art of using uneven terrain to provide protection from the enemy; in particular it will analyse the issues and events which made this military technique one of the first chapters of descriptive geometry, and the important role played by Nicolas-François-Antoine de Chastillon, the first commandant of the School of Mézières. As firearms became more powerful new studies were required about how to defend military fortifications from enemy fire. To solve these, Chastillon first highlighted the flaws of Vauban's empirical approach and then radically overhauled the study of défilement by tackling it theoretically using graphic analyses carried out 'on the drawing board'. This new approach concentrated on the depiction of space in two dimensions the need to graphically manage the territory around the fortification. Thus it is Chastillon who, well before Gaspard Monge, identified a method which was to rapidly lead to the definition of the basic operations of descriptive geometry. Together with the study of wood and stone stereotomy, it also paved the way for the new science of scientific representation, the invention of cartography and the geometric control of topographical surfaces.
\end{abstract}

Keywords Military architecture - Défilement $\cdot$ Defilade $\cdot$ Descriptive geometry · Nicolas-François-Antoine de Chastillon · École du Génie de Mézières · Eighteenth century · Representation techniques · Gaspard Monge

L. Carlevaris $(\bowtie)$

Dipartimento di Storia, Disegno e Restauro dell'Architettura, Sapienza, Università di Roma, Piazza Borghese, 9, 00186 Rome, Italy

e-mail: laura.carlevaris@uniroma1.it; lauracarlevaris@hotmail.com 


\section{Introduction}

This contribution will focus on studies concerning the art of défilement, or defilade of fortifications, that is, all those studies developed to protect points within the perimeter of a fortification from enemy fire by securing the inner space from the trajectories intersecting, in the outer space, the surroundings of the fortification (Carlevaris 2013, p. 137).

In particular we will analyse the issues and events which made this military technique one of the first chapters of descriptive geometry.

In the eighteenth century the remarkable range of new firearms had reached new heights, making défilement the trait d'union between the fortification and its immediate surroundings. As such it represents one of the first structured attempts to develop a detailed study involving the design features of fortifications and largescale representation methods.

This is the context in which the age-old problem of how to defend fortifications was analysed and tackled by the École du Génie de Mézières (The Royal School of Military Engineering, Fig. 1). Although the new approach developed by the School was based on studies by Marquis de Vauban (1633-1707) and Louis de Cormontaigne (1696-1752), it also identified their main flaws, emphasising the need to not only separate the study of défilement from empirical solutions, but also tackle it theoretically using graphic analyses carried out 'on the drawing board'.

Studies by Nicolas-François-Antoine de Chastillon (1699-1765) moved in this direction. Chastillon was the first commandant of the School of Mézières, founded in 1748 , to train the military engineers responsible for rapidly solving problems involving wartime equipment and materials. The radical change in approach to défilement imposed by Chastillon makes this military technique one of the first practical opportunities to use drawing to verify a series of operations which later became actions performed in real space; it also applied a graphic solution to very serious problems of territorial management, building, and wartime equipment. Thus from the foundation of the École Royale du Génie, défilement paved the way for this new science of scientific representation, together with the study of wood and stone stereotomy.

When reviewing the issue of défilement, it's worthwhile to adopt a broader approach to the issue of the relationship between military technique and the genesis of the classification of a design science in the mid-eighteenth century.

\section{The Plan Géométral Behind Descriptive Geometry}

Drawings used in military communications are intended to be read by large numbers of people and professionals who are not necessarily specialised or especially skilled in deciphering them; for this reason they have to be simple, but above all, coded and therefore easy to descramble. The use of a precise graphic code, as common and widespread as possible, stems from the need to provide a "reliable" communication in which each sign is univocally understood by the person who made it and by those who have to interpret it. This is particularly important when the sign corresponds to a design choice which has to be communicated to those who are responsible for 


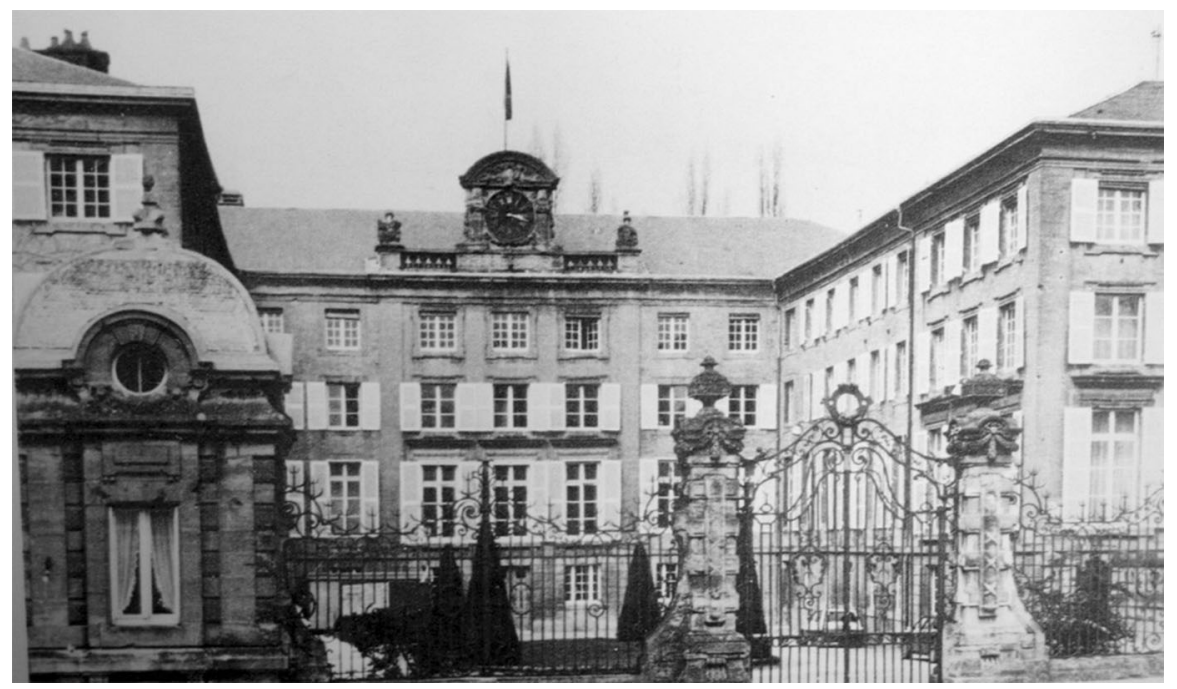

Fig. 1 The École du Génie de Mézières. Photo: public domain

implementing it. However, it is even more important when a misunderstanding can lead to uncontrolled risks, for example in military matters. Chastillon and especially the Military Engineering Corps were both acutely aware of the need to develop a scientific representation which was neither expressive or emotional, as in artistic drawings, but transmitted highly accurate information and data.

A method is said to be scientific when we realise that a practice has to be coded and subject to preliminary operations in order to simplify problems and, as a result, make them comprehensible using a common, accurate, and repeatable framework. In the case of drawings, this process of gradually becoming scientific makes them a representation method, or one of the applicative chapters of representation. This is Chastillon's contribution to the science of representation and Géométrie descriptive.

In his Traité des ombres dans le dessin géométral, written in 1763, Chastillon identified the first of the countless repercussions of this need for a scientific approach, simplification, encoding and ease of communication involving the use of light and shadows in representation. These considerations were illustrated in a small manuscript booklet which circulated in the École and was published by Théodore Olivier (Chastillon 1847). Until then, the use of shadows and light in the representation of objects - the topic of Chastillon's brief Traité-had been studied using a strictly artistic approach, empathically emphasising their effectiveness in creating what we would now call a 'realistic photo'. In other contexts, very little shading was used to show light falling on buildings; its only purpose was to indicate the plasticity of the terrain, and it was in no way intended to provide credible or plausible geographic data (Fig. 2).

Instead Chastillon considered the scientific accuracy of a line drawing as a chance to facilitate encoding, on the one hand, and decoding, on the other, 


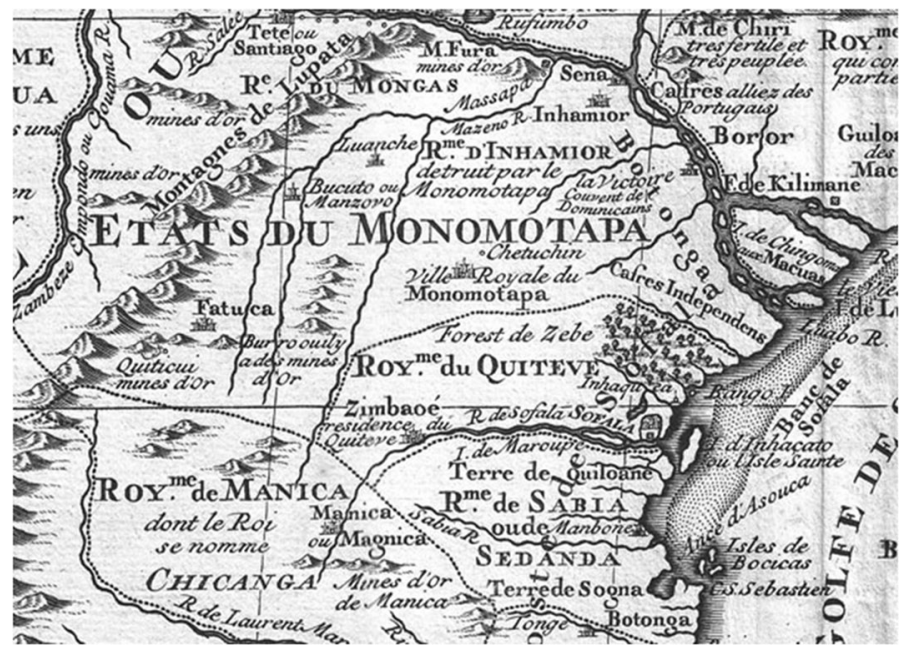

Fig. 2 Example of shading used in the representation of terrain (Forlani 1567)

validating the importance attributed by Chastillon to defining the concept of the 'user' of a drawing.

According to Chastillon, it was not aesthetics that makes a line drawing plausible, but the need to simply make it instantly easier to understand the plasticity and three-dimensionality of the real model in a drawing (Chastillon 1847: 6). The processes that he identified were: studying how light falls on the represented model, and executing the line drawing. Regarding the latter, Chastillon recommended that the draughtsman begin with the plan view, and then the elevations and sections so that their vertical planes be 'rebatted' on the plane of representation due to rotation around the vertical centreline common to the plane and the plan géométral, that is, the plane on which the drawing is created, even when-he specifies-these drawings are made on different sheets of paper (Chastillon 1847: Premise) (Fig. 3).

This approach creates a 'four-leaf' construction in which the elevations are arranged 'parallel to the lines on which it is supposed they rise. (This) facilitates examination of these parts on elevations and on the plan view ${ }^{1}$ (Chastillon 1847: Premise). This recommendation appears to immediately link the objective of military requirements to the drafting of drawings with these same requirements: to be easily and quickly interpreted. Although in this case the ensuing construction is not very original, Chastillon was admittedly very clear in his mind that the instructions for military draughtsmen also had to consider the education/expertise of those who interpreted the drawings - and this is what distinguishes drawings by architects and drawings by engineers. When Chastillon talks about engineers he refers to the members of the Military Engineering Corps for whose education he was responsible.

\footnotetext{
1 This and all translations of quotes from Chastillon are ours.
} 


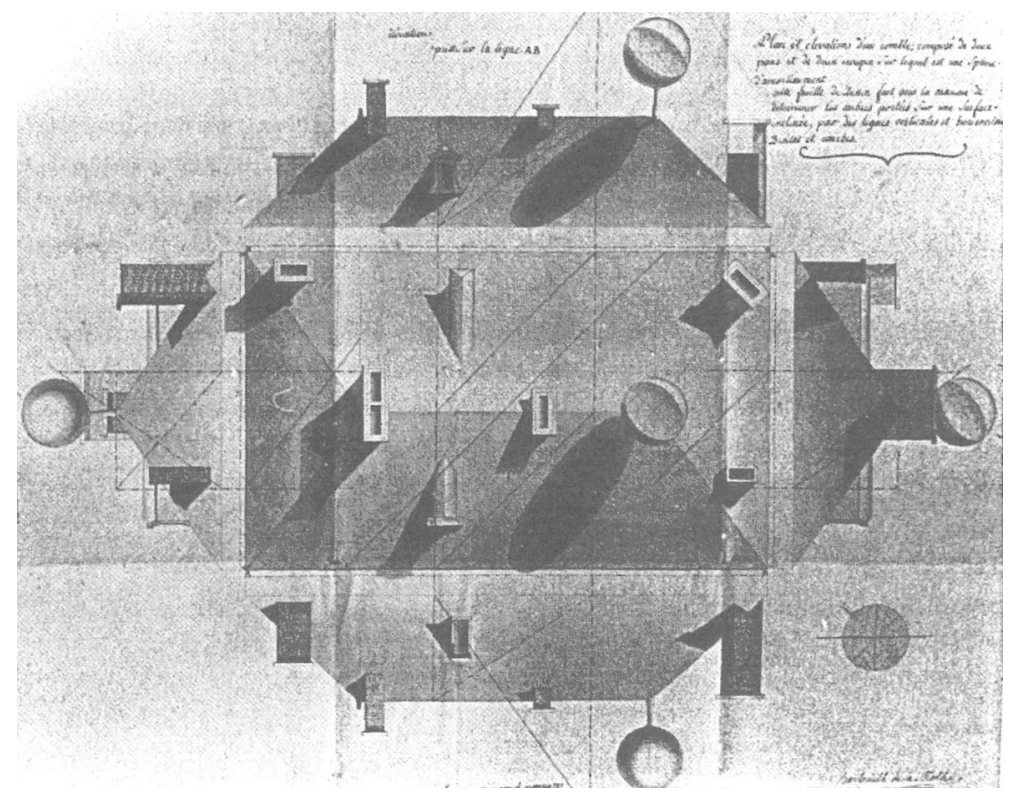

Fig. 3 Drawing of a building roof with plan, elevations and shadows according to Chastillon (1847)

The importance attributed to the plan géométral in Chastillon's treatise, as well as in teachings at Mézières indicate that its role in the genesis of descriptive geometry deserves more in-depth study. In fact, the plan géométral is the plane used to govern the projection and rebatment operations that take place in space, and on which these operations leave a graphic outline which then allows them to be recreated. Chastillon compares dessin géométral, a drawing which uses the plan géométral and is entirely based on parallel, orthogonal projections, with dessin perspective, perspective drawing, characterised by the convergence of projection rays (Chastillon 1847: 8).

Gaspard Monge (1746-1818) later concisely clarified that descriptive geometry is in fact the art of passing from three-dimensional space to graphic space (by nature two-dimensional) (Monge 1798: Programme: 2), and then retracing one's steps to visualise the real model based on the drawn model. A few years before Monge's classification, Chastillon was well aware of the basic tenets behind this scientific representation method, known as descriptive geometry-a method all too hastily attributed to Monge. ${ }^{2}$

If there are any ancient roots in Chastillon's revolutionary idea, then it is the link between dessin géométral, used by engineers (clearly military engineers) and dessin perspective, exploited by architects. However, we should not forget that Chastillon considered this difference-quickly resolved in descriptive geometry-to be the

\footnotetext{
${ }^{2}$ Monge's role in the genesis of Descriptive Geometry has sparked an interesting polemic carried forward mainly by Professors Vito Cardone and Riccardo Migliari; see (Cardone 1996) and (Migliari 1996).
} 
magic wand that did away with the idea of drawing as a mere artistic tool or tool for approximation; he reiterated and also imposed the idea that drawings had to be not only technical but also based on scientific tenets (Chastillon 1847: Premise).

Let's go back to the issue of Chastillon's proposal regarding what kind of light to use in the model; we should not forget that light clearly participates in the mental reconstruction of a spatial situation (Chastillon 1847: 10). So obviously in "engineering" drawings Chastillon recommends using a single light source, similar to sunlight (conveniently inclined parallel rays from the south), so that its incidence on the horizontal plane allows the heights of the illuminated elements to be determined by their shadow on the ground; this data was absolutely not present in a dessin géométral (Chastillon 1847: 10-13).

Lighting must therefore be realistic and geographically contextualised: an architect can perhaps afford to show shadows on a north-facing elevation, but a military engineer cannot indulge in these trifles. This graphic standard was invented so that the military, wherever they were, might interpret the drawing in the same way, since any misunderstanding could cost lives. The drawing is based on reality, but its geometric features are exaggerated so that it is like a plan de guerre. The draughtsman had to be very careful in his work in order to avoid being responsible for any dramatic consequences due to misinterpretation; the graphic construction had to be very accurate and undoubtedly had to also consider the conditions of the site, the surroundings, and finally the contextualisation of the drawing.

Chastillon's interest in light and shadow had immediate and, if truth be told, multiple consequences, even in the case of drawings for wartime purposes. First and foremost among these is the new approach he implemented regarding the study of défilement of fortifications, which he indissolubly linked to the scientific method used by the new coded science of representation (Belhoste 1992: 541).

\section{The Défilement Behind Descriptive Geometry}

It's a short step between studying the characteristics of the propagation of light and determining the shadows on buildings exposed to light, and redefining how to protect fortifications from enemy fire. This is clear especially if one looks at the duality between light rays/line of fire, illuminated surfaces/exposed and vulnerable surfaces, shadow areas/defiladed space and, also, separator of one's own shadow/ demarcation line of the parapets.

The difference, which I would call substantial, between the study of the light and the study of défilement, lies in the nature of the light source (Belhoste 1992: 541). In the light model, the light source is similar to a sphere, while in the case of the arrangement of the lines of fire it cannot be schematised in a simplified model because the enemy can position their weapons in a geographical area that is, to say the least, complex. In fact, the enemy deploys by spreading out in the immediate surroundings around the fortification; this terrain can be multifaceted, uneven, and not always easy to cope with.

So the most important problem involving défilement is to determine the space inside the fortification which must be shielded from enemy fire. In one way or another, this area must be included in the calculations made by the engineers. It 
means that the engineers have to deal with architectural issues (the fortification) and topography (the surroundings), as well as use normal drawings to portray seemingly distant elements (Carlevaris 2013). However, it also means governing the terrain itself, establishing the high points that the enemy might use to get a better view, and being able to identify the surface tangent to the terrain and the bastions of the fort below which enemy fire will not fall inside the fortification. This surface, known as surface de défilement, is the issue studied by défilement; the more uneven the terrain, the more complex it is.

To get a better understanding of how the eighteenth century constituted a turning point between an 'old' approach to war, and one which, by calling itself new, paved the way for descriptive geometry to develop, we need to take a step backwards and recall how this problem was tackled in previous centuries.

\section{Défilement Before the Eighteenth Century}

From the fifteenth to the sixteenth century, the most popular fortification was an Italian-style fortification where defence was entrusted exclusively to a complex perimeter and the inclination/slope of the bastions. Their height depended on the position of the fortification, the topography of the surroundings, and the possible presence of higher posts.

In the fifteenth century bastions were often part of "modern" fortifications, a design associated with the architects Francesco di Giorgio Martini (1439-1501) and Antonio (1455-1534) and Giuliano da Sangallo (1445-1516); these bastions were often big, heavily built corner turrets designed to strengthen the walls and obviously difficult to conquer (Fig. 4).

When the so-called Sangallo-style fortifications, with a careful study of the section of the bastion became widespread towards the end of the fifteenth century, the focus shifted to strict relationship between the walls and their immediate surroundings. This included moats, taluses, and special slopes intended to create a defilade inside the walls (Fig. 5).

With the advent of military treatises in the sixteenth century, methods which could be used to quickly and accurately build certain excavations/fortifications on site began to circulate in Europe. The area outside the fortification involved in the remodelling began to get larger and larger. The focus rapidly shifted from the study of the profile of the rampart to the remodelling of large areas of the immediate surroundings thanks to extensive earthworks. During the sixteenth century, one of the chapters always present in military treatises focused on how to move huge amounts of earth through soil excavation and filling and how to reuse the removed soil in order to quickly prepare the war zone. This problem was closely linked to contemporary geometric knowledge since it involved pinpointing the location of huge amounts of earth which had to either be removed or remodelled in order to prepare the terrain for attack or defence manoeuvres, bearing in mind the need to contain costs and reduce man hours. ${ }^{3}$

\footnotetext{
${ }^{3}$ This issue was addressed in many treatises starting in the sixteenth century; see (Limana 2007, esp. pp. 97-165).
} 


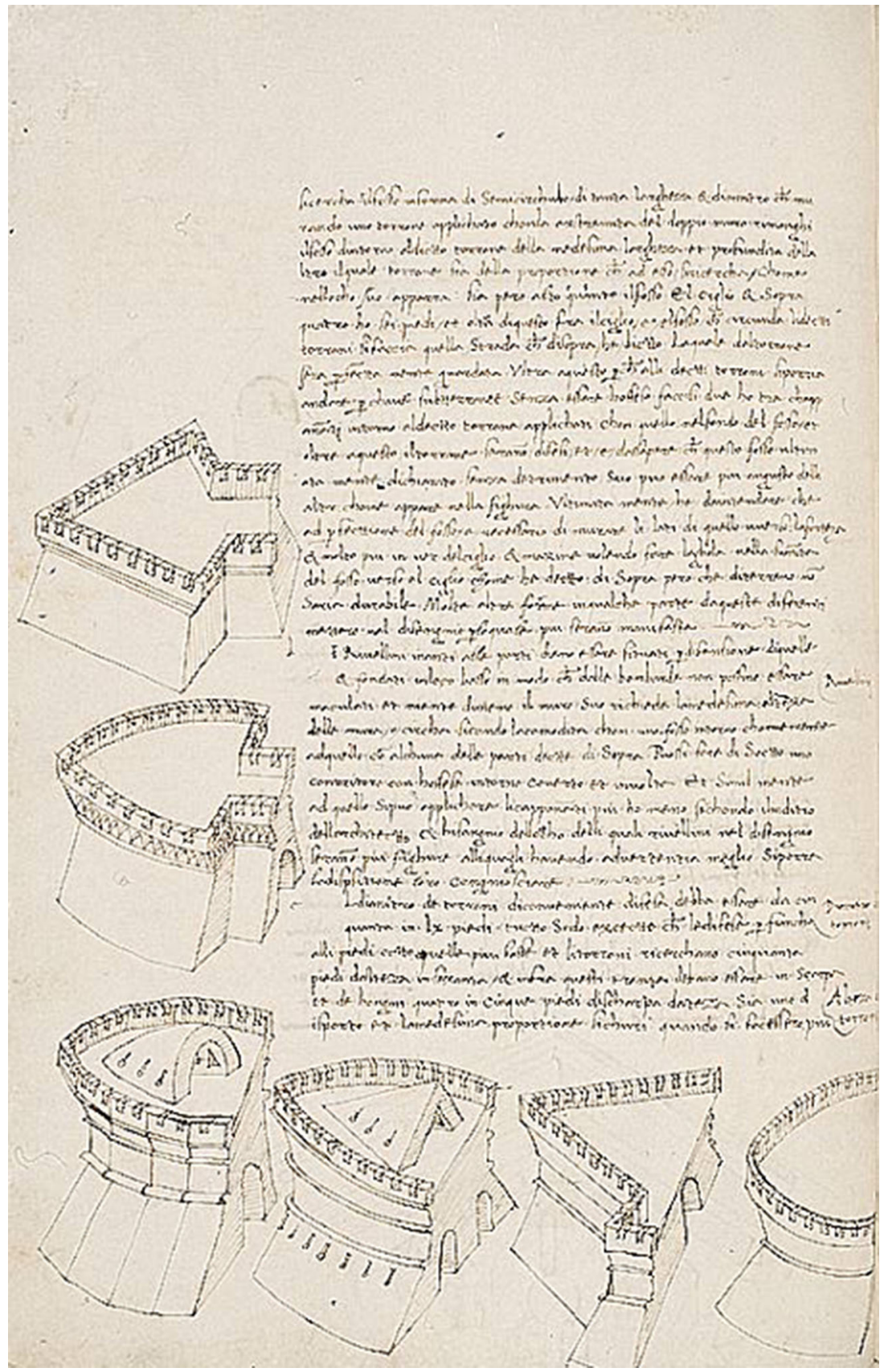

Fig. 4 Francesco di Giorgio Martini, a few examples of bastions, from "Trattato di architettura civile e militare" (ca. 1490), Codex Magliabecchiano II. 1. 141, fol. 53r. Reproduced by permission of Biblioteca Nazionale Centrale, Firenze 


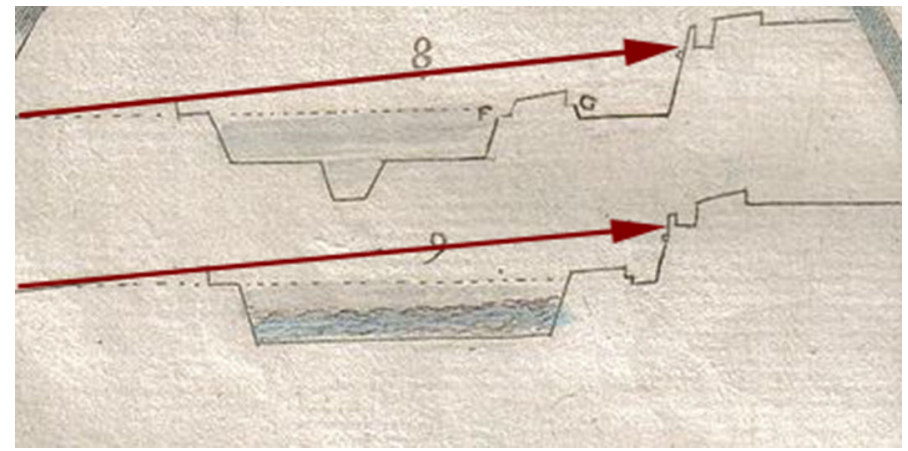

Fig. 5 Re-elaboration of a Sangallo-style fortification. Note the moat, the excavations at the foot of the fortification, and the tall walls which protect the area inside the perimeter. Image: author

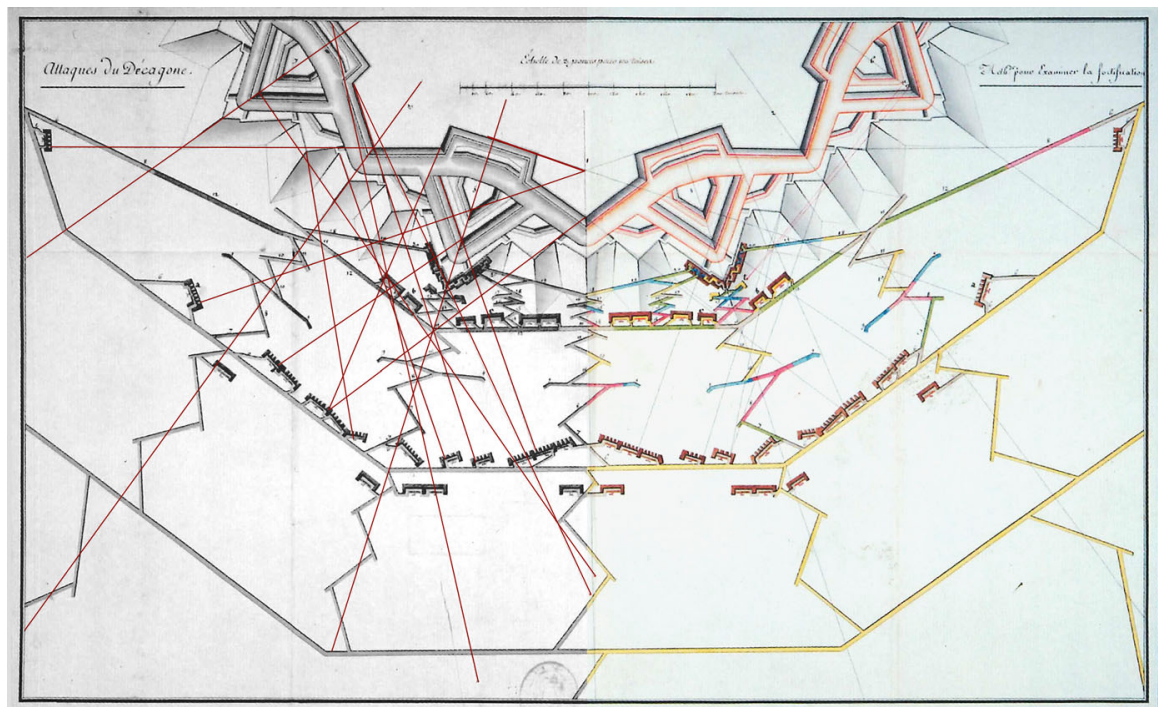

Fig. 6 Study of a fortification during a Vauban siege (drawing by Fourcroy de Ramecourt); on the left side, the lines of fire are marked by the present author

In the seventeenth century when weapons and their range of fire were improved, the perimeter of fortifications seemed to dissolve and spread out in several directions in order to block enemy fire. Fortifications and fortified cities began to become increasingly star-shaped and a sort of competition started to see how skilled architects were in designing these complex structures. Drawings of the perimeter and bastions began to show the possible lines of fire, and défilement became the daily bread of anyone required to design the layout of a new defensive fortification (Fig. 6).

However, military representations were still restricted to the use of the plan géométral where the lines of fire may have been considered either horizontal or 
inclined, but could have never done justice to the exact topographical conformation of the immediate surroundings.

The early eighteenth century saw the advent of weapons, such as canons, which could fire as far away as 1,400 m; trellis-work, wooden gantry cranes, and other devices appeared on the battlefield. Their purpose was to elevate the weapons and strike from the top downwards into the fortification.

This is the moment when the study of défilement becomes very similar to the geometric study of lines of fire and the orography of the surroundings. The different customs and drawings had to necessarily deal with the building, land, and surroundings, topics which were usually tackled separately since they could not be represented on the same graphic scale.

During the eighteenth century, studies involving large-scale documentation of the land began to classify new representation systems, but also and above all new metric and morphological acquisition systems. Representation systems now used valuable new tools and techniques; at the end of the century this process favoured, on the one hand, a new universal unit of measure (the meter) and, on the other, to the drafting of maps portraying increasingly bigger parts of the territory and proper territorial survey campaigns, such as those commissioned by Napoleon Bonaparte (1769-1821) and executed by his military engineers (Carlevaris 2010: 201ff.) (Fig. 7).

Since the Military Engineering Corps was responsible for all the attack and defence infrastructures in France, this became an important cultural point of reference during the period of transformation began in the seventeenth century and early eighteenth century, in particular, in the work carried out by Vauban. Vauban was the first person who tried to control and defend France by adopting a single system, identifying the places where it was possible to build an extensive network of fortifications to defend France's borders (Fig. 8).

Vauban also explored the surroundings of these fortifications to find out where lines of fire might come from and, as a result, establish the right height of each edge of the polygonal line at the end of the parapet walk of the fortification.

Vauban proposed an essentially empirical method also used by Cormontaigne: several soldiers were sent around the fortification to verify critical points. Armed with poles and stakes, they visualised the common plane at each critical point and at the polyline created by stretches of the curtain wall, or better still at each stretch of the curtain wall itself; this broke a complex problem down into a much simpler and easier-to-solve problem. In other words, this plan de site, site plane, is the limit above which there is the real possibility of being hit by enemy fire, and below which a person is relatively safe.

Clearly this is a very efficient but incredibly dangerous system since the soldiers have to venture into potentially hostile territory: the system is slow and needs to be repeated several times. Vauban, however, has to be credited with having proposed a solution to the complex problem of défilement that took into account the need to study the fortification and surroundings simultaneously; the survey was carried out using a planchette (an easily transported tool comprising a small flat piece of wood on which are placed a piece of paper, an alidade to sight the points and measure the position using angles of collimation, and a compass for direction) and other contemporary tools. 


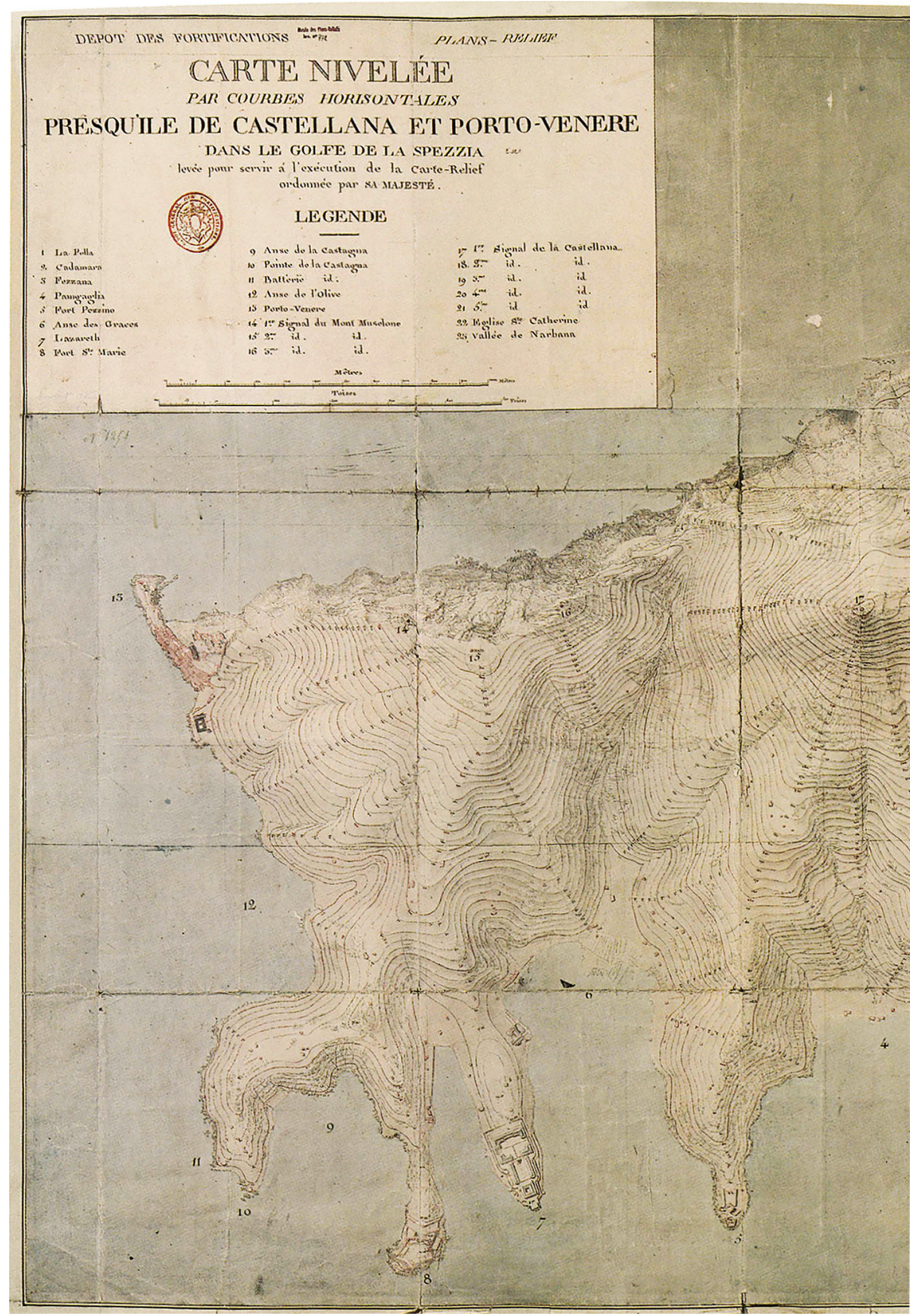

Fig. 7 Napoleon's Military Engineering Corps. Detail of Carte nivelée par courbes horizontales de la presqu'île de Castellana et Porto-Venere. Image: Musée des Plans-Reliefs de Paris, INV. 772. Art. IV, carton 4) 


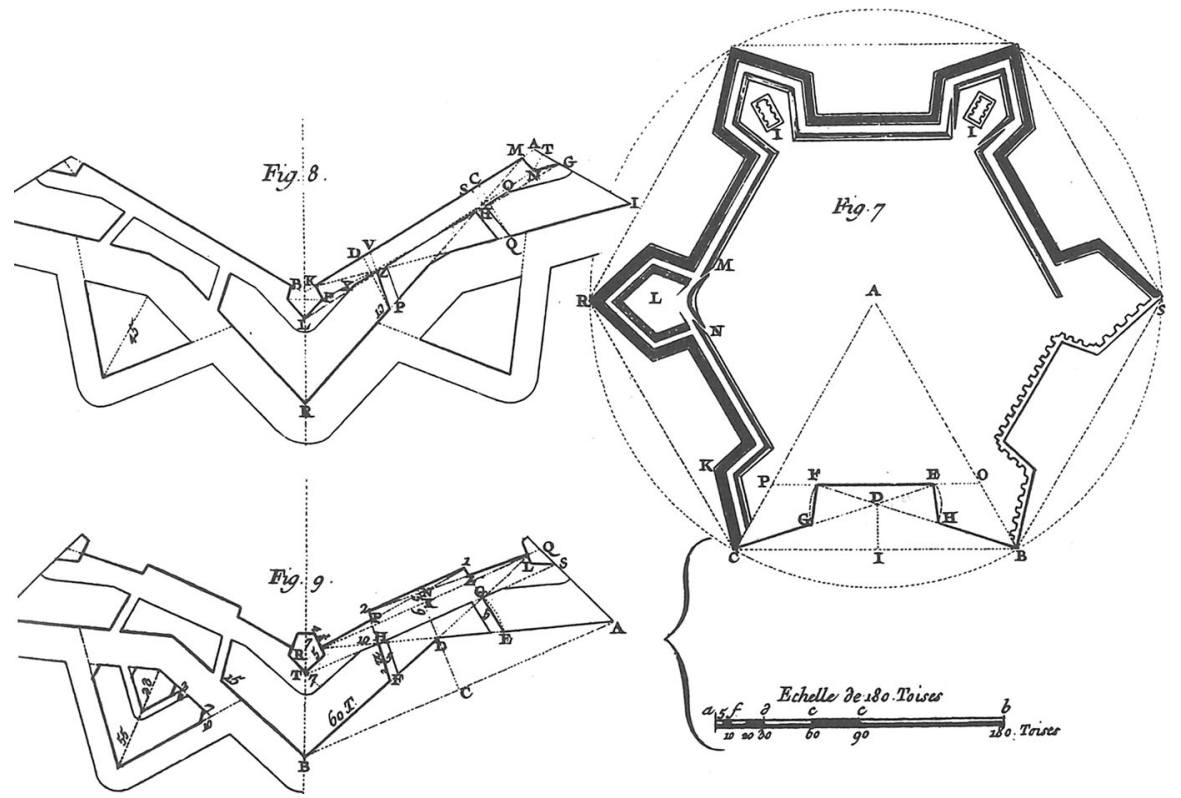

Fig. 8 Fortification systems developed by Vauban, as depicted in the Encyclopédie, ou Dictionnarire raisonné des sciences, des arts et des métiers, par une société de gens de lettre, mis en ordre et publié par M. Diderot et quant à la partie mathématique, par M. d'Alembert (Paris: Briasson, 1751-1756), Art Militaire, Fortification, Planche II

In the mid-eighteenth century Vauban's solution was heavily criticised; as a result, Chastillon's renewed study of défilement within the framework of the École du Génie de Mézières initially focused on finding solutions to the problems inherent in this empirical method.

\section{Défilement at Mézières}

The École du Génie de Mézières was founded in France in 1748 to train military personnel so that they could technically master the new and much more powerful weapons of war. After all the very resounding defeats of the previous 50 years, France decided to renew and improve its army; it started by focusing on young officers whose training had become obsolete and inadequate, as had the seventeenthcentury defensive systems which were still in use.

When Chastillon was nominated First Commandant of the School and had to draft a training programme, his interest focused immediately on the educational aspect and application of the study of défilement. In fact, he instantly developed a new approach to the issue; by separating the study of the plan de site, site plane, from the empirical tests ordered by Vauban and Cormontaigne he not only avoided sending soldiers into enemy territory, but also imposed a theoretical approach to the issue: Chastillon's innovative method involved the analysis of existing cartography to study the relationship between the fortification and the territory. 
The main tool used in this approach to the design and improvement of fortifications was the analysis of the plan coté and the carte cotée, contour plans and layouts in which the height of the points compared to a horizontal reference plan are combined with the orthogonal projection of the spatial points on the plane of representation. By forcing his pupils to use this analysis as an instrument, Chastillon prompted a shift from an empirical approach to a theoretical solution; this was the first step towards a systematic and scientific approach to an objective problem. In actual fact, what he did was to bring the study of défilement closer to the embryonic science of scientific and encoded representation officially considered to have been invented by Monge (Cardone 1996; Migliari 1996).

It was possible to adopt Chastillon's new approach thanks to the new survey and large-scale graphic restitution tools which during that period had begun to produce excellent results. In fact, beginning with Edmond Halley's studies of magnetic phenomena, graphic restitution could now use major graphic tools to portray the lie of the land and hillsides, including contour lines, the establishment of important points (maximum or minimum altitude), and the description of salient lines (ridges, valley floors, coastlines, maximum gradients, etc.) (Carlevaris 2010).

In Chastillon's innovative approach imposed at the École (starting with the very first study course syllabus), both trainee students and the military used these new graphic tools. Chastillon had divided the training programme into two separate yet complementary sections (Taton 1986). The theoretical training (the so-called école de théorie) involved classroom lessons which were held mainly during the winter months (Belhoste et al. 1990: 73-81; Belhoste 1997); these lessons included drawing exercises (épures and tracés), building models, stone and wood cutting, siege and defence tests, and the study of défilement and Vauban's approach to fortification. The practical training (école de pratique) was held mostly in the field, with open-air survey exercises, interpretation and implementation of maps, contour measurements and map dimensioning, fortification layouts, attack and defence of sites, and défilement (Belhoste et al. 1990: 53; Lambert and Thibault 2011: 60). Although theory and practice were initially taught separately, in later school programmes they became basically complementary and increasingly interdependent as part of a comprehensive and autonomous education and training course. The study of stereotomy was intended to teach students the rules governing an engineering-style drawing; défilement was meant to show them how to survey the land and buildings as well as teach them the geometric rules required to deal with the projection and rebatment of planes. According to Chastillon, drawing was the link between stereotomy and the study of défilement, because drawing was needed for both. He believed that careful control of representation was the only tool that was truly of assistance in a civil or military project. Furthermore, if stereotomy is a trait d'union between survey and design (Belhoste 1990: 108), the same is true for défilement, which involves the survey of the surrounding landscape and, if it exists, of the fortification requiring an intervention to render it adequate in the face of new developments, on one hand, and a design approach in the improvement of an existing fortification or in the construction of a new defensive infrastructure, on the other (Belhoste 1990: 108, 109). 
Chastillon later initiated two new Projets de Règlement. The Programme was reviewed in 1760 and involved the establishment of a new École des appareilleurs et de conducteurs de travaux des fortifications, a school for those who prepare and carry out the work of fortifications, to train subordinate technical personnel for the corps of engineers (Le Puillon de Boblay 1862: 31-33: Chastillon 1764a: art. 18; Taton 1986: 578-580; Belhoste 1990: 3-8). In this programme Chastillon emphasises the joint study of drawing and wood and stone stereotomy which in turn represents, as we all know, one of the first fields of learning that used the science of representation (Migliari 2001). The new Règlement of the École required these subjects to be studied at the beginning of the students' 2-year training (Taton 1986: 576-578). Chastillon was always a firm believer in the need for army technical support personnel to have studied these subjects in-depth. He had written a few years earlier:

Quite apart from the fact it is useful to know how to cut stone and wood for construction or to build real works these skills pave the way to more exact and accurate knowledge about how to draw plans and sections, and the best way to portray the survey which has to be represented; in fact they can be considered as equally important as (Euclid's) Elements (Chastillon 1754).

In the second half of the eighteenth century, défilement became an important part of the genesis of the science of representation which was beginning to be studied, albeit not yet systematically, in Mézières; this was due to the importance attributed to the study of défilement as the practical application of a graphic technique to solve a problem, and the fact that it was compared to survey techniques and stereotomic design.

What we need to study now is how Chastillon tackled défilement practically so that we can understand how his treatise developed in the few years that elapsed between his work and the publication, at the end of the century, of Monge's Géométrie descriptive (1798).

Although Chastillon's new solution to the problem of défilement pre-empted the studies published a few years later, the time was not yet ripe for him to be able to say that his graphic solution could solve any and all topographical problems. In fact, in his practical example, he only tackles the problem of a site on level ground, in other words where the context was simpler to explore graphically. In fact, if the ground is flat, then the plan de site, site plane, is horizontal, and so is the plane of défilement, which passes through each edge of the polygonal line at the ends of the curtain wall (Chastillon 1764a: 2-4; 1764b: 3; Belhoste 1992: 542).

Simplifying the context allowed Chastillon not only to reduce to a minimum the number of operations needed to solve the problem, but also to avoid making complex, reiterated calculations.

The end of the century was now only 40 years away, a period during which défilement was increasingly tackled systematically and mastered thanks to the fact that techniques, procedures and operations became part of the methods of descriptive geometry. 
Défilement after Chastillon: du Vigneau, Monge, and their Successors

After Chastillon it was his pupil Antoine-Nicolas-Bernard du Vigneau (1716-1795) who continued working on défilement. Around the year 1766 du Vigneau finally considered a generic case of a fortification with uneven terrain in its immediate vicinity. Based on the teachings of his teacher, he used carte cotée in his approach, but took it one step further towards a geometric approach to the issue. In fact, du Vigneau identified the plane which belongs to one point of the fortification and to two points of the surroundings, chosen from amongst the highest in the area. du Vigneau was looking for an inclined plane which necessarily had to pass above ground without cutting through it.

To verify this approach du Vigneau had to analyse each altitude point by point, once again falling into the trap of having to repeat the operations over and over.

Monge was the one who solved this problem elegantly by rebatting vertical planes chosen ad hoc (Figs. 9, 10). The problem of défilement was one of the first issues tackled by the young draughtsman in Mézières; ${ }^{4}$ he chose an unusual geometric approach (Sakarovitch 1998: 229) which avoided the repeated calculations required by both Vauban's method and Chastillon's complex graphic operations.

Monge was able to solve the problem in a geometrically impeccable manner thanks to progress in the field of territorial description techniques which, as mentioned earlier, were rapidly evolving into the large-scale geographical survey campaigns implemented a few years later in Europe (Carlevaris 2010).

Monge considered the visual cone with a vertex in a point of the fortification (let $A$ be this point) as the base of the visible uneven surroundings seen from $A$. This was a generic cone, tangent to the ground (Langins 2004: 247). The cone is created by the envelope of the infinite planes tangent to the ground itself. This is the plan de site, site plane, compared to which every point of the fortification has to be defiladed, and must therefore be at a lower altitude.

Monge then draws the projection of each individual generatrix of the cone on the horizontal plane that also belongs to $A$. The projecting planes are therefore vertical: rebatting them will create, on the plane of the graphic construction, the section curves of the ground which will all pass through $A$. Now, when rebatting each plane, it is possible to stretch the tangent from $A$ to the maximum level of the section curves. This makes it impossible for the tangents in a point of the section curve to cut through the curve itself. These tangent straight lines to the section curve in its maximum height point are the lines which, all together, create the surface de site (extension in space of the plan de site) which in turn creates the surface de défilement.

The points below the surface de défilement are protected ("defiladed"), while the ones above it are instead liable to be open to enemy fire, and are therefore vulnerable posts.

\footnotetext{
${ }^{4}$ It was Chastillon, or perhaps du Vigneau, who invited Gaspard Monge to Mézières in 1765-1766 as a teacher of exercises in the Drawing course set up by Chastillon himself (Belhoste 1992: 541).
} 

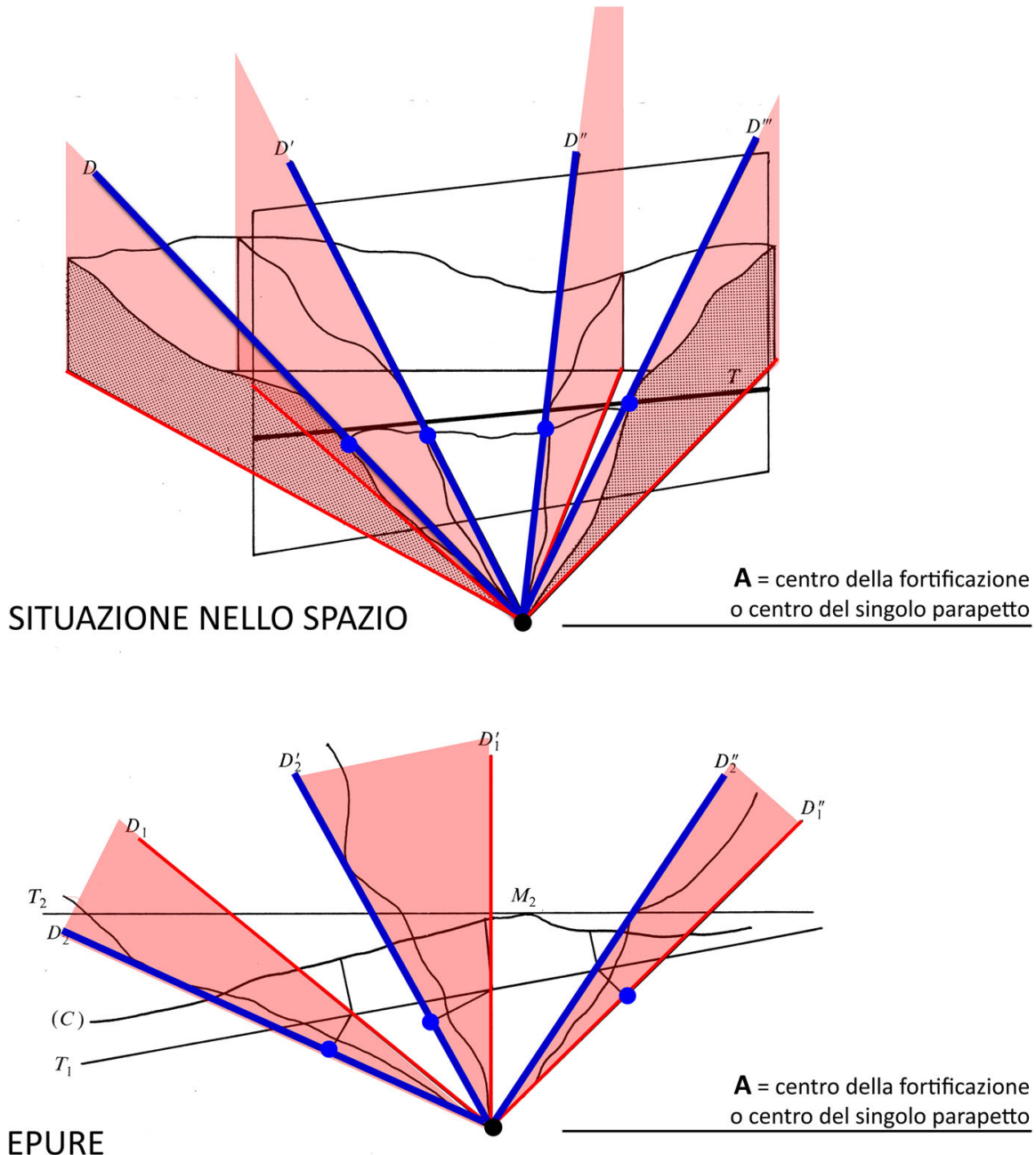

Fig. 9 Re-elaboration of the drawing by Belhoste (1992: p. 544): vertical planes in light red. The planes belong to the straight lines tangent to the section curves (in blue). Below: rebatment on the plane of construction of the vertical planes. Image: author (colour figure online)

This approach is closely linked to Monge's new geometric acquisitions regarding surfaces and tangent planes. A few years later it helped Pierre-Louis-Georges du Buat (1734-1809) (Barré de Saint-Venant 1866) define a new geometric concept, one which was to be crucial in the study of défilement and scientific, metrically controlled techniques for describing the land (du Buat 1768). By introducing the concept of the maximum gradient of a straight line, du Buat also introduces the échelle de pente, level of slope, of this particular straight line and inclined planes (Carlevaris 2010: 208). It was Monge and Jean-Pierre-Nicholas Hachette 


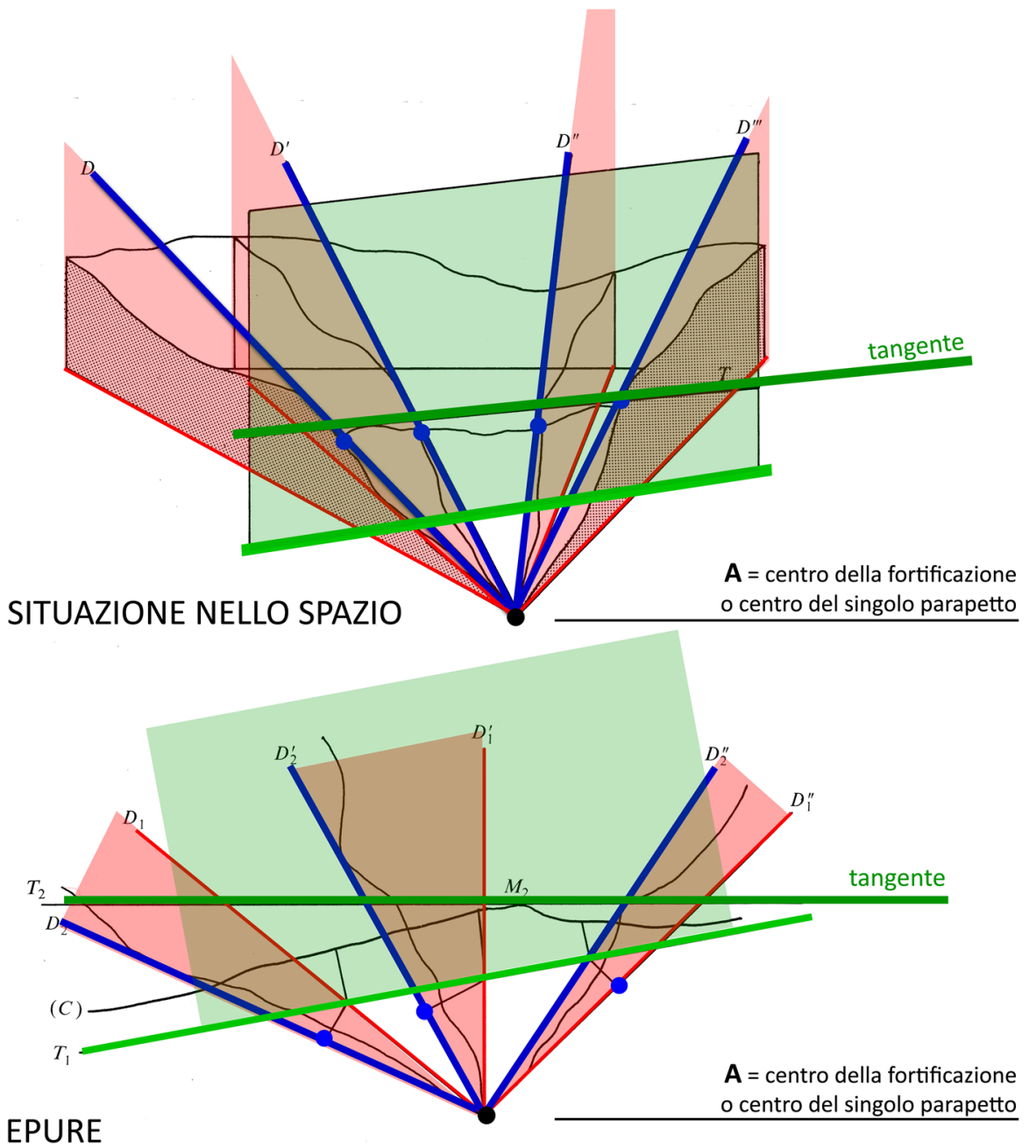

Fig. 10 Re-elaboration of the drawing by Belhoste (1992: p. 544): identification of the straight line representing the tangent of the section curves of the terrain at their highest altitude (in green) and the vertical plane belonging to this straight line (again in green). Below: rebatment of the vertical plane passing through the tangent. Image: author (colour figure online)

(1769-1834) who extended this concept to topographical surfaces, identifying what was later called the échelle de défilement, level of defilade (Hachette 1828).

The 'rebatments' implemented by Monge were soon associated, in the work by Jean Baptiste Meusnier de la Place (1754-1793), with the nascent description of the territory using contour lines, making it much easier to build section curves with the auxiliary vertical planes (Meusnier de La Place 1777: 12) (Fig. 11).

Towards the end of the century Horace Say (1771-1799) resumed studies on the link between défilement and the treatment of shadows (Belhoste 1992: 541), the importance of which was strenuously supported by Chastillon, as mentioned earlier. 


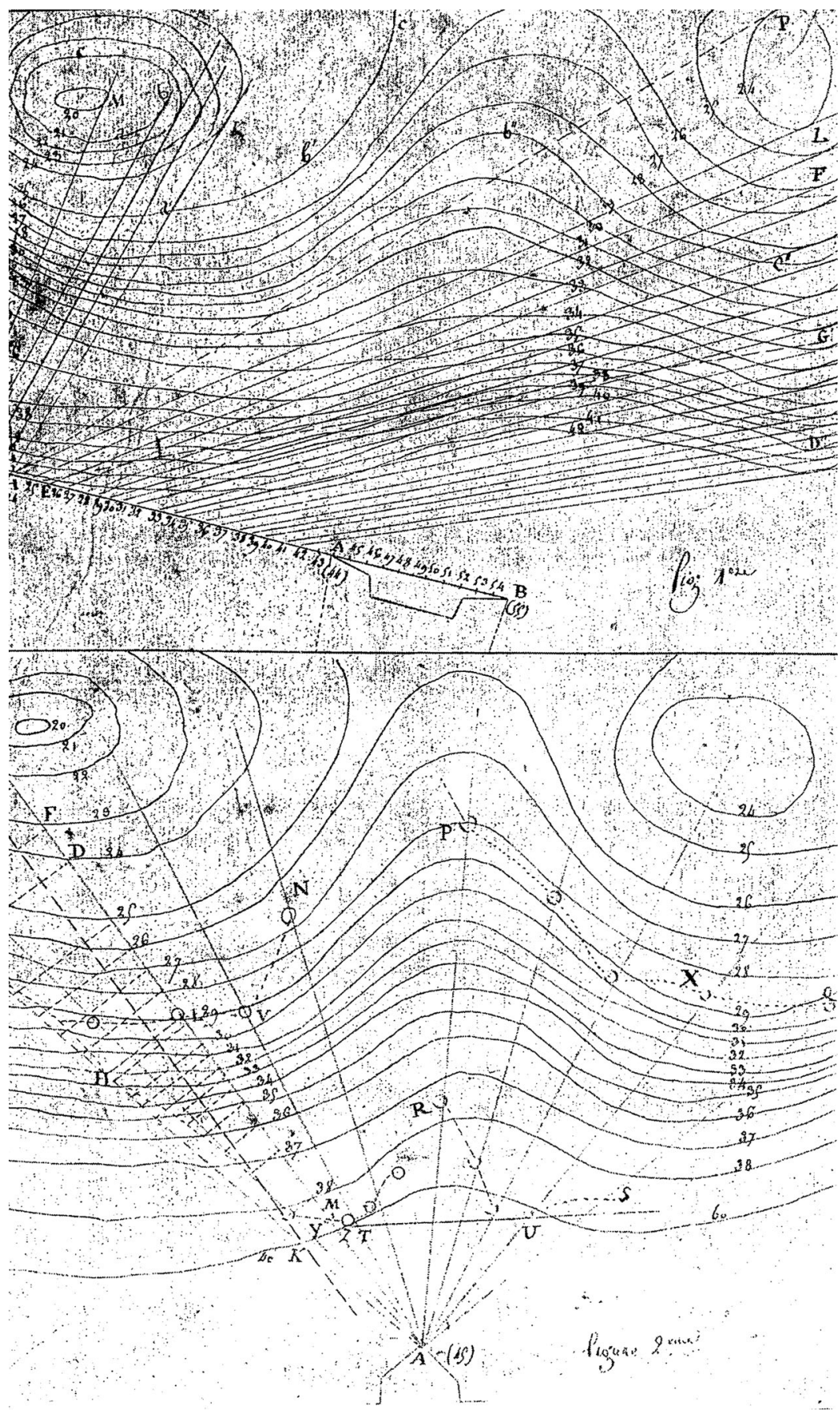

Fig. 11 Jean-Baptiste Meusnier de La Place, method for solving the problem of défilement (Meusnier de La Place 1777) 

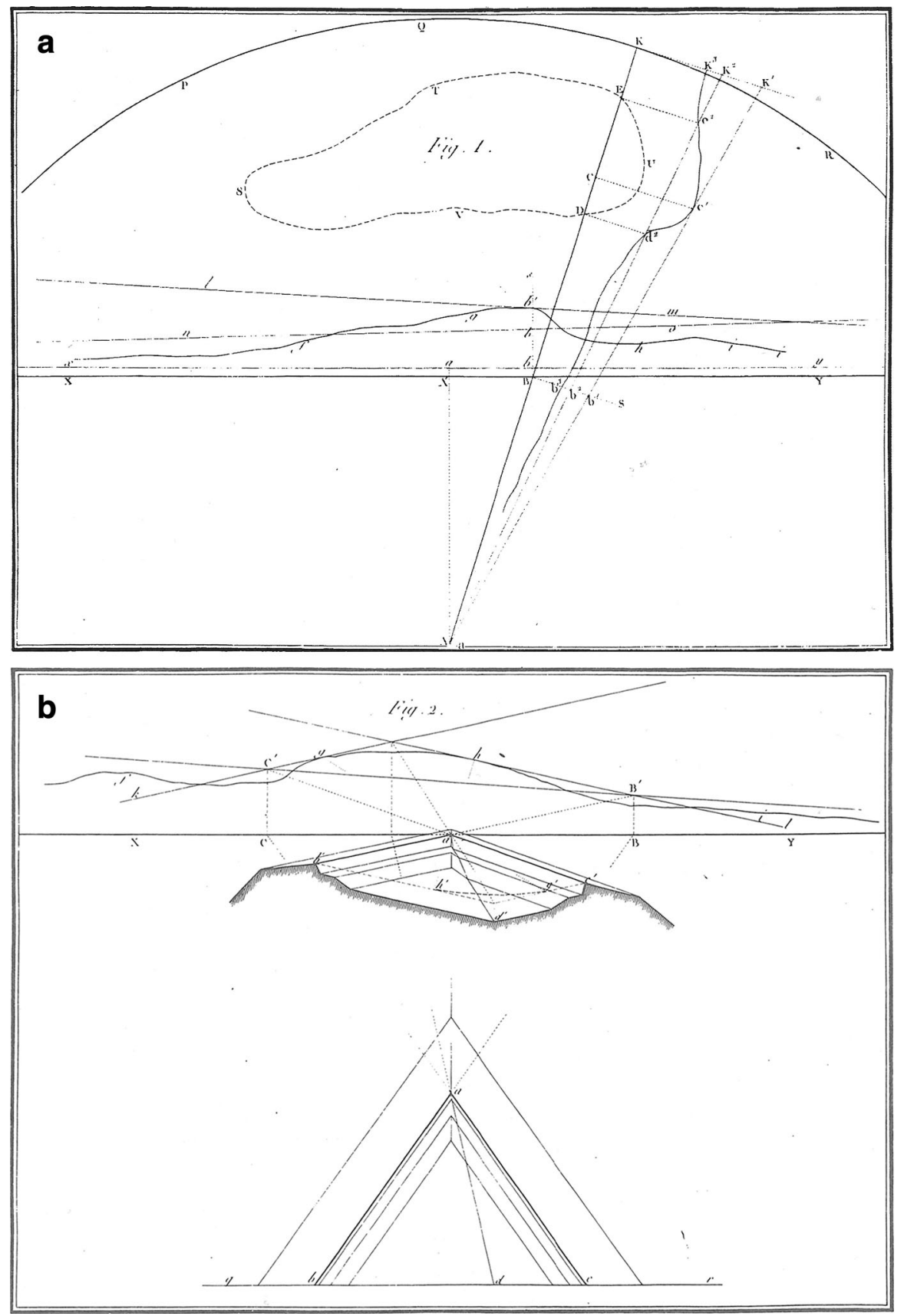

Fig. 12 Horace Say, solution to the problem of défilement (Say 1796) 
In Say's work, a defiladed space was described as a shadow area containing all the protected points of the fortification: the parapets intercept and break the lines of fire just like a body which, when hit by light rays, stops them and creates its shadow on the ground.

Although Say tackles défilement based on Monge (and improves his method) (Fig. 12), the best thing he did was undoubtedly to present défilement as a fullblown, graphically defined tactic. At long last his drawings can be interpreted, and the text also tackles the problem of finally establishing the necessary terminology.

At the end of the eighteenth century, défilement had become one of the applicative methods of the new science of representation, a science which also sparked an important momentum towards motivation, definition and approach.

It is without a doubt thanks to Chastillon that this defensive technique became an important issue in the scientific culture of the latter part of the eighteenth century; it was his work which gave technical drawings a key role in the education and training of the corps of engineers. Chastillon wrote:

One of the first rules we are committed to at the Engineering School in Mézières is to teach young officials the principles of drawing with a method. When it's easy to express oneself with a pencil, and draw comprehensible drawings, then military installations, their construction, layout, and suitable height of the fortifications, will all be correctly executed... (Chastillon 1847: Premise).

This new approach to the study of drawing led to the birth and classification of the concepts on which the science of descriptive geometry is based: projecting points and rebatting planes onto other planes, especially onto the graphic construction plane; 200 years later, digital representation-permeated by those concepts - is also based on those same roots. Here we have to acknowledge the importance of warfare's contribution to science, an inheritance which we would all like to eradicate, entrusting knowledge to much nobler origins.

\section{References}

Barré de Saint-Venant, Jean Claude. 1866. La vie et les ouvrages de Pierre-Louis-Georges, Comte du Buat. Lille: Imprimerie L. Danel.

Belhoste, Bruno. 1990. Du dessin d'ingénieur à la géométrie descriptive. L'enseignement de Chastillon à l’École royale du génie de Mézières. Extenso June 1990: 103-135.

Belhoste, Bruno, Antoine Picon, and Joël Sakarovitch, eds. 1990. Les exercices dans les écoles d'ingénieurs sous l'Ancien Régime et la Révolution. Histoire de l'éducation 46: 53-109.

Belhoste, Bruno. 1992. Les problèmes de défilement. In Leçons de mathématiques. Édition annotée des cours de Laplace, Lagrange et Monge avec introductions et annexes, Annexe 16, 541-546. Paris: Dunod.

Belhoste, Bruno. 1997. L'alliance entre théorie et pratique. De l'enseignement de l'art des fortifications à la création de Polytechnique. La Recherche 300: 40-45. http://www.larecherche.fr/savoirs/dossier/ alliance-entre-theorie-pratique-01-07-1997-80438. Accessed 3 Nov 2014.

Bélidor, Bernard Forest. 1729. La science des ingénieurs dans la conduite des travaux de fortification et d'architecture civile. Paris: C. Jombert.

Cardone, Vito. 1996. Gaspard Monge scienziato della rivoluzione. Naples: CUEN. 
Carlevaris, Laura. 2010. La rappresentazione quotata tra storia e prospettive. In Attualità della Geometria descrittiva. Seminario nazionale sul rinnovamento della Geometria descrittiva, eds. Laura Carlevaris, Laura De Carlo, Riccardo Migliari, 201-228. Roma: Gangemi.

Carlevaris, Laura. 2013. Edificio e territorio: il défilement come trait d'union nell'opera di Chastillon. In Proceedings of the Conference Città e Territorio. Conoscenza, tutela e valorizzazione dei paesaggi culturali (Massa Marittima, Grosseto, November 2012), 136-143. Livorno: Debatte.

Chastillon, Nicolas-François-Antoine de. 1754. Projet de règlement sur l'ordre et la police de l'instruction donnè à l'école du génie établie à Mézières. Archives de l'Inspection du Génie, art. 18, section 1.

Chastillon, Nicolas-François-Antoine de. 1847. Traité des ombres dans le dessin géométral (1763). In Applications de géométrie descriptive aux ombres, à la perspective, à la gnomonique et aux engranages, ed. Théodore Olivier, 5-26. Paris: Carilian-Goeury et V. Dalmont.

Chastillon, Nicolas-François-Antoine de. 1764a. De l'exercice de la fortification. Ms. Archives de l'Inspection du Génie, art. 18, section 3.

Chastillon, Nicolas-François-Antoine de. 1764b. Traité du relief, commandement et défilement de la fortification à l'usage des écoles du Génie à Mézières. Ms. Archives de l'Inspection du Génie, I, art, 18 , section 3.

Du Buat, Pierre-Louis-Georges. 1768. Sur le relief et le défilement des ouvrages de fortification, où l'on indique une nouvelle méthode pour déterminer le tracé de l'enceinte des places relativement aux différents terrains irréguliers qui se peuvent rencontrer. Bibliothèque du Service historique de la Défense, Ms. 471.

Forlani, Paolo. 1567. Descrizione del Piemonte. Venice: Paolo Forlani.

Hachette, Jean Nicolas Pierre. 1828. Cours de Géométrie descriptive, comprennent les applications de cette géométrie aux ombres, à la perspective et à la stéréotomie. Paris: Corby: VI.

Lambert, Guy, and Estelle Thibault, ed. 2011. L'atelier et l'amphithéâtre. Les écoles de l'architecture, entre théorie et pratique. Wavre: Éditions Mardaga.

Langins, Janis. 2004. Conserving the enlightenment. French Military Engineering from Vauban to the Revolution. Cambridge, MA-London: MIT Press.

Le Puillon de Boblay, Théodore. 1862. Notices sur les Écoles du Génie de Mézières et de Metz. Metz: Russeau-Pallez.

Limana, Mirko Maria. 2007. La costruzione dell'immagine architettonica nei trattati di architettura militare del Cinquecento. Le origini della "prospettiva soldatesca". Ph.D. thesis, Sapienza Università di Roma.

Meusnier De La Place, Jean-Baptiste. 1777. Mémoire sur la Détermination du Plan de Site. Ms. Archives de l'Inspection du Génie, art. 21, section 1.

Migliari, Riccardo. 1996. La vita e l'opera di Monge: critica di un'apologia. XY dimensioni del disegno XXVII/XXVIII: 22-28.

Migliari, Riccardo, ed. 2001. Il disegno e la pietra. Dal Partenone alla Colonna Traiana. Rome: Gangemi.

Monge, Gaspard. 1798. Géométrie Descriptive. Leçons données aux Écoles Normales ..., Programme: 2. Paris: Baudouin.

Sakarovitch, Joël. 1998. Épures d'architecture. De la coupe des pierres à la géométrie descriptive. XVI XIX ${ }^{e}$ siècle. Basel-Boston-Berlin: Birkhäuser.

Say, Horace. 1796. Mémoire sur le défilement des fortifications. Journal de l'École Polytechnique 2: 588-616.

Taton, René. 1986. L’École royale du Génie de Mézières (1964). In Écoles techniques et militaires au XVIII ${ }^{e}$ siècle, eds. Roger Hahn and René Taton, 559-615. Paris: Hermann. (First published in René Taton, Enseignement et diffusion des sciences en France au XVIII siècle, Paris, Hermann, 1964).

Laura Carlevaris received her Ph.D. in Survey and Representation of the Environment and Architecture, from Sapienza, Rome University on the topics of ancient perspective and its application in the Hall of the Masks of the House of Augustus on the Palatine Hill. She has worked as a Research fellow since 2008 at the Sapienza University of Rome in the Department of History, Drawing and Conservation of Architecture of the Faculty of Architecture. Her research interests and publications focus on the history and methods of descriptive geometry and its fields of application, such as the origin of representation methods starting from ancient perspective, quoted projections and orthogonal projections. She is 
investigating new digital tools as well as the relationships between urban configuration and historical transformations. Her interests in descriptive geometry and architectural representation also extends to topics of new digital tools and the way they relate on the one hand to traditional graphic expression, and on the other to geometry and its development. 